\title{
Vertical distribution of the radon concentration at Batu Pahat district, Johor, Malaysia
}

\author{
Muneer Aziz Saleh a, c*, Syed Nurhaizam bin Syed Othman ${ }^{\text {b }}$, Khaidzir Bin Hamzah a, Jasman \\ Zainal $^{\text {a }}$ \\ a Nuclear Engineering Programme, Faculty of Chemical and Energy Engineering, Universiti Teknologi Malaysia, 81310 Skudai, Johore Bahru, \\ Johor, Malaysia \\ b Department of Physics, Faculty of Science, Universiti Teknologi Malaysia, 81310 Skudai, Johor Bahru, Johore, Malaysia \\ c National Atomic Energy Commission ( NATEC), Sana'a, Yemen \\ *Corresponding author: mouneersaleh@yahoo.com
}

\section{Article history}

Received 1 July 2019

Revised 3 October 2019

Accepted 5 January 2020

Published Online 15 June 2020

Graphical abstract

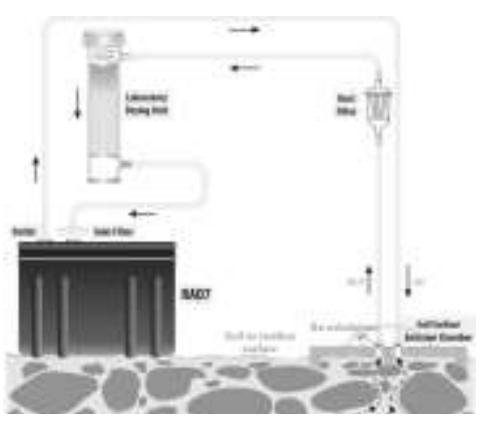

\section{Abstract}

This study investigated the vertical distribution of radon, ${ }^{222} \mathrm{Rn}$ concentrations in soil gas for different soil types and found the relation between the measured gamma dose rates and radon concentrations. The ${ }^{222} \mathrm{Rn}$ concentrations in soil gas were measured at depth of $20 \mathrm{~cm}, 60 \mathrm{~cm}, 80 \mathrm{~cm}$ and $100 \mathrm{~cm}$ using semiconductor detector (RAD7) coupled with soil gas probe. The overall activity concentrations of ${ }^{222} \mathrm{Rn}$ in soil were ranged from Minimum Detectable Activity (MDA) to $54000 \pm$ $3000 \mathrm{~Bq} \mathrm{~m}^{-3}$ in Batu Pahat District. The results showed that the overall highest concentration of ${ }^{222} \mathrm{Rn}$ was recorded at $40 \mathrm{~cm}$ depth for most of the soil types, which could be the most reliable for taking the radon measurements than other depths. Soil type 32 (Dystric Nitosolse Orthic FerrasolsRengam Jerangau) has the highest radon concentration, which was $12,462 \pm 5237 \mathrm{~Bq} \mathrm{~m}^{-3}$. The gamma dose rates (GDR) above $1 \mathrm{~m}$ were measured using portable survey meters (Ludlum 19). A good relationship between radon concentrations in soil gas and the measured gamma dose rates was observed using Pearson Correlation. The results of ${ }^{222} \mathrm{Rn}$ concentration in soil gas obtained from this study were in agreement with results reported by other researchers.

Keywords: Radon, soil gas, RAD7, Gamma dose rate.

(C) 2020Penerbit UTM Press. All rights reserved

\section{INTRODUCTION}

The main sources of ionizing radiation in the earth crust, to which humans are continuously exposed, are uranium, thorium and their progeny in the environment (Sharama et al., 2011). Radon is a naturally occurring radioactive gas which can be found everywhere in our environment. It is chemically inert, cannot be seen nor its odour perceived in the environment. It has several isotopes, but the isotopes of interest for this study were ${ }^{222} \mathrm{Rn}$ (Radon) and ${ }^{220} \mathrm{R}$ (Thoron), due to their availability in the environment and negative health impacts on humans (Abumurad and Al-tamimi, 2005).

Radon is transferred from its origin by diffusion for longer distances and finally blown out into the atmosphere. The discharge of radon depends mainly on radium content and mineral grain size, as well as geophysical and geochemical parameters that rule its transport in the earth, in which its discharge is guided by hydro meteorological environments (Etiope and Martinelli, 2002).

Radon in the soil gas, which contributes the largest percentage of radon in indoor air, is considered to be a good predictor of radon potential in a given site (Nazaroff et al., 1988). In addition, soil gas permeability, which is closely related to the migration of radon gas, has been revealed by previous studies for determining the room-entry rate of radon ( Yasuoka et al., 2010).
Soil is very essential to living things, especially humans. Therefore, soil type is important and must be controlled and protected. The largest natural source of radiation exposure to humans is radon gas that exists in air, water and soil. Since radon gas has always been in the environment, its contribution to human radiation exposure has increased in recent years (Audeem et al., 1993). Radon exposure can vary depending on the soil and rock structure beneath buildings. The radon concentration in soil gas was our main concern in the current study, thus the data obtained would be useful in understanding the behaviour of radon and its mobility in the environment and could be used for radiological protection purposes.

\section{EXPERIMENTAL}

\section{The study area}

The study area was Batu Pahat district and it lies southeast of Muar, southwest of Kluang, northwest of Pontian and south of Segamat and new Ledang district. Its population is approximately 417,458. These districts are increasing in line with current developments. However, it has 525 gazetted villages and village-clusters where smaller villages are annexed to their bigger immediate neighbors for the purpose of administration (Department of Statistics, Malaysia, 2015). 


\section{Type of soil in Batu Pahat district}

The soil type in the study area could be classified into its soil code based on Table 1 (Department of Agriculture Peninsular Malaysia, 1973), which were Fluvisols, Gleysols, Dystric Gleysols, Nitosols, Ferrasols, Acrisols, Histosols and miscellaneous soils (Saleh et al., 2013; Department of Agriculture Peninsular Malaysia). Fluvisols includes two types of soil species, namely Thionic Fluvisols locally (known as Kranji) and Dystric Fluvisols that known as Telemong Akob. Ferrasols consists of Orthic Ferrasols, Rhodic Ferrasols, Plinthic Ferrasols and Xanthic Ferrasols. Acrisols group can be found in small areas across Batu Pahat District. The scientific names of this group are Ferric Acrisols and Orthic Acrisols. Histosols is a common soil type that covers the vast area in between Parit Raja and Ayer Hitam, Johor, which is in the middle part of Batu Pahat district. Locally known as peat soil, it is classified as Dystric Histosols. Miscellaneous soils such as steep land and urban land are also found in the area of Batu Pahat urban area (Saffuwan et al.,2012).

Table 1 Soil types within the study area.

\begin{tabular}{|c|c|c|}
\hline \multicolumn{2}{|r|}{ Soil type } & \multirow[b]{2}{*}{ Local name } \\
\hline Label & FAO UNIT & \\
\hline 1 & $\begin{array}{l}\text { Humic Podzols -Dytstric } \\
\text { Fluvisols }\end{array}$ & Rudua- Rusila \\
\hline 2 & Thionic Fluvisols & Keranji \\
\hline 3 & Thionic Fluvisols & Linau- Sedu \\
\hline 5 & $\begin{array}{l}\text { Vertic Cambisols-Eutric } \\
\text { Gleysols }\end{array}$ & Selangor-Kangkong \\
\hline 8 & $\begin{array}{l}\text { Dystric Gleysols- Humic } \\
\text { Gleysols } \\
\text { Humic Gleysols-Dystric } \\
\text { Histosols }\end{array}$ & $\begin{array}{l}\text { Briah- Organic Clay } \\
\text { and Muck } \\
\text { Organic Clay and } \\
\text { Muck }\end{array}$ \\
\hline 10 & Dystric Histosols & Peat \\
\hline 11 & Dystric Fluvisols & $\begin{array}{l}\text { Telemong Akob- local } \\
\text { Alumina }\end{array}$ \\
\hline 18 & $\begin{array}{l}\text { Xanthic Ferrasols - } \\
\text { Dystric Gleysols }\end{array}$ & Holyrood Lunas \\
\hline 21 & $\begin{array}{l}\text { Orthic Acrisols - Ferric } \\
\text { Acrisols }\end{array}$ & Batu Anam -Durian \\
\hline 22 & $\begin{array}{l}\text { Orthic Acrisols - Plinthic } \\
\text { Ferralsols } \\
\text { Plinthic Ferralsols- }\end{array}$ & $\begin{array}{l}\text { Batu Anam-Melaka - } \\
\text { Tavy } \\
\text { Melaka- Tavy- Gajah }\end{array}$ \\
\hline 25 & $\begin{array}{l}\text { Plinthic Ferralsols } \\
\text { Ferric Acrisols - Ferric }\end{array}$ & $\begin{array}{l}\text { Mati } \\
\text { Serdang -Bungor - }\end{array}$ \\
\hline 31 & $\begin{array}{l}\text { Acrisols -Orthic } \\
\text { Ferrasols }\end{array}$ & Munchong \\
\hline 32 & $\begin{array}{l}\text { Ferrasols } \\
\text { Dystric Nitosols - Orthic }\end{array}$ & Rengam- Jerangau \\
\hline 36 & & Prang \\
\hline 43 & $\begin{array}{l}\text { Rhodic Nitosols - Ferric } \\
\text { Acrisols }\end{array}$ & Kulai-Yong Peng \\
\hline 49 & Steep land & Tanah churam \\
\hline 50 & Urban Land & Tanah bandar \\
\hline
\end{tabular}

\section{Radon measurement for soil gas}

The concentrations of radon in soil gas were measured at different depths profile for various soil types within the study area. The radon concentration was measured at each point at depth of $20 \mathrm{~cm}, 40 \mathrm{~cm}, 80$ $\mathrm{cm}$ and $100 \mathrm{~cm}$ from the ground, using a semiconductor detector known as RAD7 (Durridge company Inc. 2015), RAD7 is an instrument that converts radiation from the decay to the electric signal.

During the measurement, the detector was first purged for at least $10 \mathrm{~min}$, with relative humidity observed to be less than $6 \%$. The detector was then connected with stainless steel probe (internal diameter of 0.25 inch) via a small desiccant tube containing $\mathrm{CaSO}_{4}$ and inert filter that would suck soil gas from the depth. The soil gas samples were collected from the depth without exposing them to the outside air. The soil gas probe contained hollow tube with a hole near the tip that dipped inside the soil gently with stroke of hammer at adepth of $20 \mathrm{~cm}$, $40 \mathrm{~cm} 60 \mathrm{~cm}, 80 \mathrm{~cm}$ and $100 \mathrm{~cm}$ from the ground. The surface soil around the probe was tamped to avoid leakage of fresh air into the soil gas at the depth. The soil was sucked through the tube pipe into the measuring instrument for 5 min pumping phase for 4 cycles to obtain accurate results, a process which took about $30 \mathrm{~min}$. The detector is an instrument that converts alpha radiation from the decay of ${ }^{222} \mathrm{Rn}$ to electric signal. It is developed for measurements of radon in any kind of air; indoor air, outdoor air and soil. The detector amplifies, filters and sorts the signal according to its strength. It is insensitive to beta and gamma radiation, so there will be no interference from beta emitting gases or from gamma radiation fields. The location of each sampling point was recorded with a global positioning system (GPS). The instrument sensitivity for radon was $0.0130 \mathrm{cpm} /\left(\mathrm{Bq} \mathrm{m}^{-3}\right)$ normal mode and $0.00624 \mathrm{cpm} /\left(\mathrm{Bq} \mathrm{m}^{-3}\right)$ for sniff mode under the following conditions; mean temperature of $18.5{ }^{\circ} \mathrm{C}$, flow rate of $0.853 \mathrm{~L} / \mathrm{min}$, equilibration period of $5 \mathrm{~min}$ and spill factor of 0.016 ). The overall calibration error was estimated to be within $+/-5 \%$.

\section{RESULTS AND DISCUSSION}

The radon concentrations in different soil types at different depths

The mean activity concentrations of ${ }^{222} \mathrm{Rn}$ for each soil type at 20 $\mathrm{cm}$ depth were presented in Fig. 1. Soil type 32 (Dystric NitosolseOrthic Ferrasols -Rengam Jerangau), located at the area of Minyak Beku Mukim, has the highest mean activity concentrations of ${ }^{222} \mathrm{Rn}$ with a value of $1330 \pm 219 \mathrm{~Bq} \mathrm{~m}^{-3}$. The lowest mean activity concentrations of ${ }^{222} \mathrm{Rn}$ was found to be $6 \pm 18 \mathrm{~Bq} \mathrm{~m}^{-3}$ at Kajang River Village, which covered by soil type 2 (Thionic Fluvisols -Kranji).

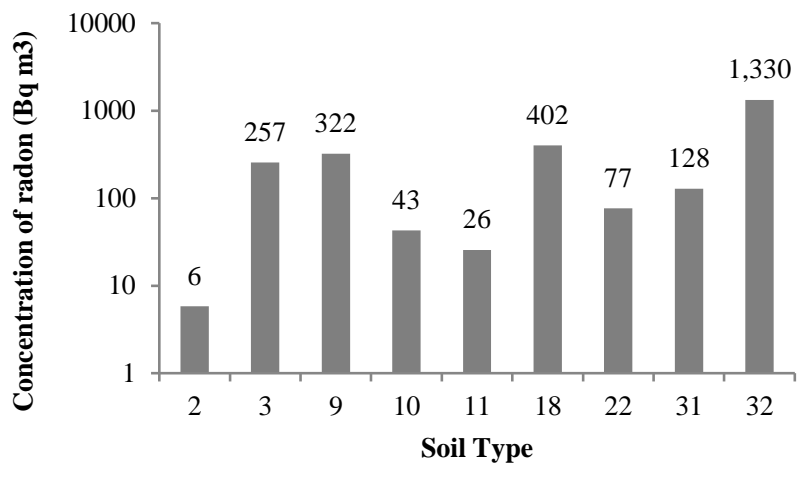

Fig 1. The mean activity concentrations of ${ }^{222} \mathrm{Rn}$ in different soil types at $20 \mathrm{~cm}$ depth.

Fig. 2 shows the results of the mean activity concentrations of ${ }^{222} \mathrm{Rn}$ at $40 \mathrm{~cm}$ depth for different soil types. Soil type 9 (Humic GleysolsDystric Histosols-Organic Clay and muck), which is dominant at Yong Peng Mukim, has the highest mean activity concentrations of ${ }^{222} \mathrm{Rn}$, which was $54000 \pm 3000 \mathrm{~Bq} \mathrm{~m}$. The lowest mean activity concentrations of ${ }^{222} \mathrm{Rn}$ was found at Kajang River Village, which has a soil type 2 (Thionic Fluvisols -Kranji).

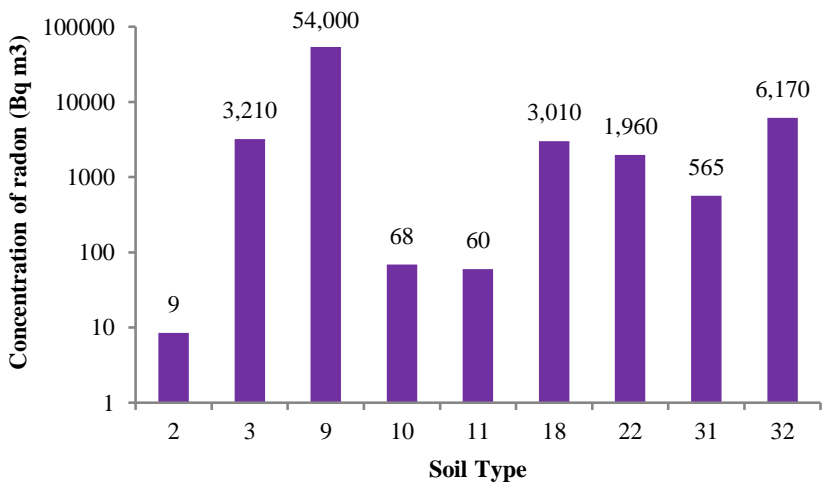

Fig 2. The mean activity concentrations of ${ }^{222} \mathrm{Rn}$ in different soil types at $40 \mathrm{~cm}$ depth. 
The mean activity concentrations of ${ }^{222} \mathrm{Rn}$ for each soil type at $80 \mathrm{~cm}$ depth were presented in Fig. 3. Soil type 32 (Dystric NitosolseOrthic Ferrasols -Rengam Jerangau) has the highest mean activity concentrations of ${ }^{222} \mathrm{Rn}$ of $9610 \pm 886 \mathrm{~Bq} \mathrm{~m}$, while soil type 11 (Dystric FluvisolseDystric Gleysol-Telemong Akobelocal alluvium) has the lowest mean activity concentrations of ${ }^{222} \mathrm{Rn}$ with a value of 9 $\pm 17 \mathrm{~Bq} \mathrm{~m}^{-3}$, found at the area of Bagan Mukim.

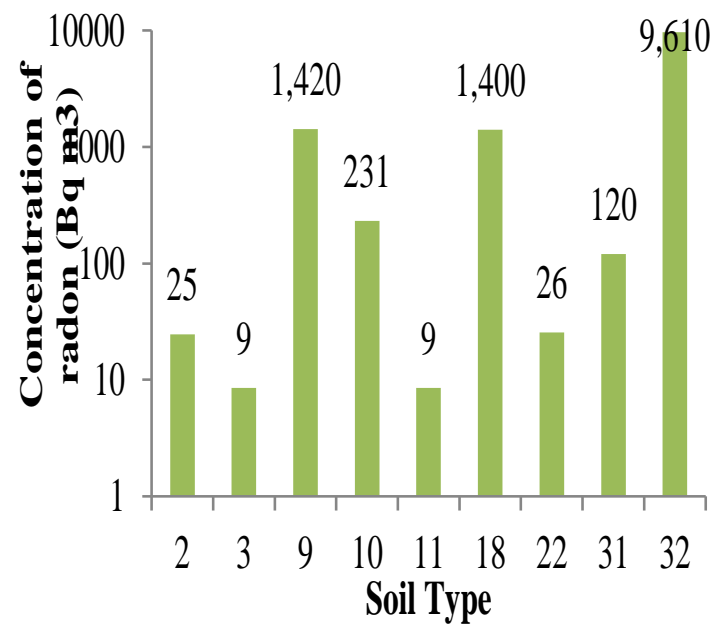

Fig 3. The mean activity concentrations of ${ }^{222} \mathrm{Rn}$ in different soil types at $80 \mathrm{~cm}$ depth.

Fig. 4 shows the results of the mean activity concentrations of ${ }^{222} \mathrm{Rn}$ for $100 \mathrm{~cm}$ depth at different soil types. Soil type 32 (Dystric NitosolseOrthic Ferrasols -Rengam Jerangau) has the highest mean activity concentrations of ${ }^{222} \mathrm{Rn}$ of $32400 \pm 2060 \mathrm{~Bq} \mathrm{~m}^{-3}$, while the lowest the mean activity concentrations of ${ }^{222} \mathrm{Rn}$ was found to be $9 \pm$ $17 \mathrm{~Bq} \mathrm{~m}^{-3}$ at $\mathrm{Hj}$ Mohd Noor Trench and the area was covered by soil type 18 (Xanthic Ferrasolse Dystric Gleysols -Holyrood Lunas).

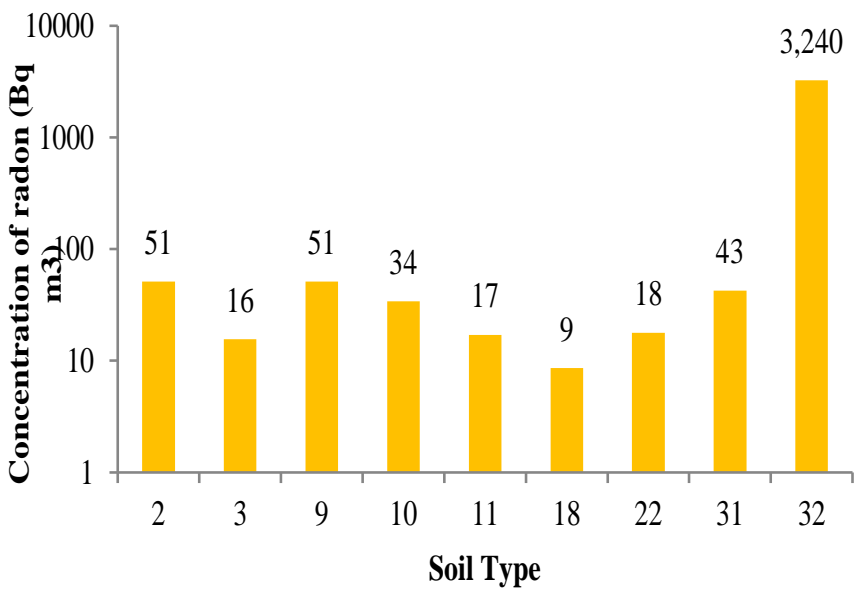

Fig 4. The mean activity concentrations of ${ }^{222} \mathrm{Rn}$ in different soil types at $100 \mathrm{~cm}$ depth.

Fig. 5 shows the vertical distribution of the mean activity concentrations of ${ }^{222} \mathrm{Rn}$ in different soil types. For Soil type 2 (Thionic Fluvisols) and Soil type 32 (Dystric NitosolseOrthic Ferrasols-Rengam Jerangau), the mean activity concentrations of ${ }^{222} \mathrm{Rn}$ were increased with depth, with the highest activity concentrations of ${ }^{222} \mathrm{Rn}$ was recorded at $100 \mathrm{~cm}$ depth while the lowest activity concentration of ${ }^{222} \mathrm{Rn}$ was recorded at $20 \mathrm{~cm}$ depth.

Soil type 2 (Thionic Fluvisols), soil type 9 (Humic GleysolsDystric Histosols), Soil type 11 (Dystric Fluvisolse Dystric Gleysol), Soil type 18 (Xanthic Ferrasolse Dystric Gleysols), Soil type 22 (Orthic Acrisolse- Plinthic Ferralsols) and soil type 31 (Ferric Acrisolse Ferric AcrisoIse Orthic Ferrasols) recorded the highest mean activity concentrations of ${ }^{222} \mathrm{Rn}$ at $40 \mathrm{~cm}$ depth.

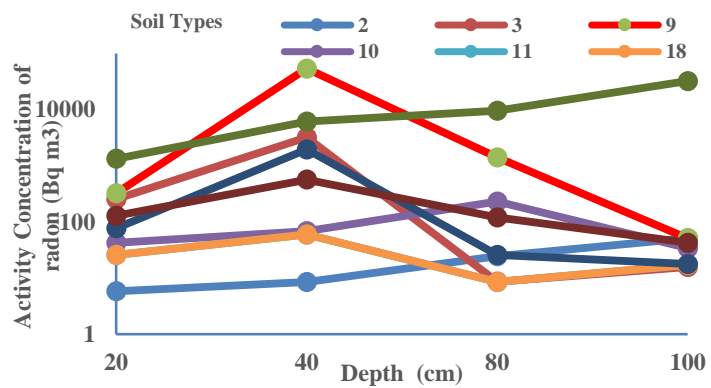

Fig 5. Overall vertical distribution of the mean activity concentrations of ${ }^{222} \mathrm{Rn}$ in different soil types

Table 2 shows the overall mean activity concentrations of ${ }^{222} \mathrm{Rn}$ at different depths. The overall highest mean activity concentrations of ${ }^{222} \mathrm{Rn}$ at $40 \mathrm{~cm}$ depth was $4291 \pm 464 \mathrm{~Bq} \mathrm{~m}^{3}$. The overall lowest mean activity concentrations of ${ }^{222} \mathrm{Rn}$ was found at the depthof $20 \mathrm{~cm}$ with value of $180 \pm 77 \mathrm{~Bq} \mathrm{~m}^{3}$.

Table 2. Overall mean activity concentrations of ${ }^{222} \mathrm{Rn}$ in different soil types.

\begin{tabular}{|c|c|c|c|c|c|}
\hline \multirow[b]{2}{*}{$\begin{array}{l}\text { Depth } \\
\text { (cm) }\end{array}$} & \multicolumn{5}{|c|}{ Mean activity concentrations of ${ }^{222} \mathrm{Rn}$ for the soil types $\left(\mathrm{Bq} \mathrm{m}^{3}\right)$} \\
\hline & $\begin{array}{l}\text { Thionic } \\
\text { Fluvisols }\end{array}$ & $\begin{array}{l}\text { Thionic } \\
\text { Fluvisols }\end{array}$ & $\begin{array}{l}\text { Humic } \\
\text { Gleysols - } \\
\text { Dystric } \\
\text { Histosols }\end{array}$ & $\begin{array}{c}\text { Dystric } \\
\text { Histosols }\end{array}$ & $\begin{array}{c}\text { Dystric } \\
\text { Fluvisol } \\
\text { se } \\
\text { Dystric } \\
\text { Gleysol }\end{array}$ \\
\hline 20 & $6 \pm 10$ & $257 \pm 81$ & $322 \pm 87$ & $43 \pm 43$ & $26 \pm 33$ \\
\hline 40 & $9 \pm 17$ & $3210 \pm 134$ & $54000 \pm 3000$ & $68 \pm 74$ & $60 \pm 43$ \\
\hline 80 & $25 \pm 48$ & $9 \pm 17$ & $1420 \pm 242$ & $231 \pm 99$ & $9 \pm 17$ \\
\hline 100 & $51 \pm 65$ & $16 \pm 31$ & $51 \pm 65$ & $34 \pm 40$ & $17 \pm 34$ \\
\hline \multirow[b]{2}{*}{$\begin{array}{l}\text { Depth } \\
\text { (cm) }\end{array}$} & \multicolumn{5}{|c|}{ Mean activity concentrations of ${ }^{222} \mathrm{Rn}$ for the soil types $\left(\mathrm{Bq} \mathrm{m}^{3}\right)$} \\
\hline & $\begin{array}{c}\text { Xanthic } \\
\text { Ferrasolse } \\
\text { Dystric } \\
\text { Gleysols }\end{array}$ & $\begin{array}{c}\text { Orthic } \\
\text { Acrisolse - } \\
\text { Plinthic } \\
\text { Ferralsols }\end{array}$ & $\begin{array}{c}\text { Ferric } \\
\text { Acrisolse } \\
\text { Ferric } \\
\text { Acrisolse } \\
\text { Orthic } \\
\text { Ferrasols } \\
\end{array}$ & $\begin{array}{c}\text { Dystric } \\
\text { Nitosolse } \\
\text { Orthic } \\
\text { Ferrasols }\end{array}$ & $\begin{array}{c}\text { Overall } \\
\text { Mean }\end{array}$ \\
\hline 20 & $402 \pm 129$ & $77 \pm 17$ & $128 \pm 71$ & $1330 \pm 219$ & $180 \pm 77$ \\
\hline 40 & $3010 \pm 277$ & $1960 \pm 243$ & $565 \pm 106$ & $6170 \pm 286$ & $\begin{array}{c}4291 \pm 46 \\
4\end{array}$ \\
\hline 80 & $1400 \pm 212$ & $26 \pm 51$ & $120 \pm 59$ & $9610 \pm 886$ & $800 \pm 181$ \\
\hline 100 & $9 \pm 17$ & $18 \pm 24$ & $43 \pm 33$ & $32400 \pm 2060$ & $\begin{array}{c}1938 \pm 26 \\
3\end{array}$ \\
\hline
\end{tabular}

\section{In-situ gamma dose rate measurement}

The mean gamma dose rate was plotted to study the variation for gamma dose rate based on soil type, as presented in Fig. 5. Soil type 32 (Dystric NitosolseOrthic Ferrasols -Rengam Jerangau) has the highest gamma dose rate, which was $190 \mathrm{nGy} \mathrm{h}^{-1}$, while soil type 18 (Xanthic Ferrasolse Dystric Gleysols -Holyrood Lunas) has the lowest gamma dose rate with a value $60 \mathrm{nGy} \mathrm{h}^{-1}$.

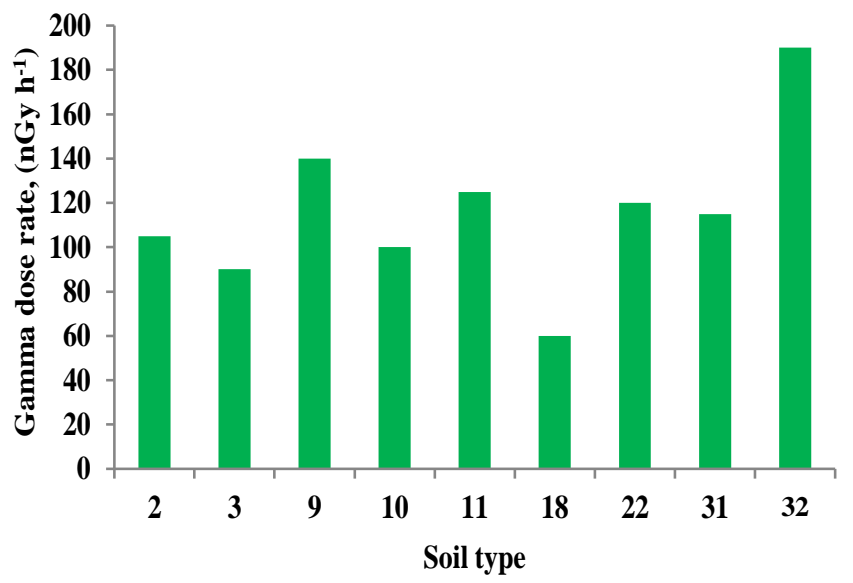

Fig 6. The mean gamma dose rate reading with different soil types. 


\section{The relationship between gamma dose rate and activity concentrations of ${ }^{222} \mathrm{Rn}$}

The gamma dose rate was related to the radon activity concentrations in different types of soil. Soil type 32 (Dystric Nitosols Orthic Ferrasols-Rengam Jerangau) has the highest gamma dose rate of $190 \mathrm{nGy} \mathrm{h}^{-1}$. Soil type 18 (Xanthic Ferrasolse Dystric GleysolsHolyrood Lunas) has the lowest gamma dose rate, with a value of 60 $n G y h^{-1}$. Figure 7 shows the relation between gamma dose rate and activity concentrations of radon. It showed a good relationship between radon concentrations and gamma dose rates with correlation coefficient of $\mathrm{R}=0.75$.

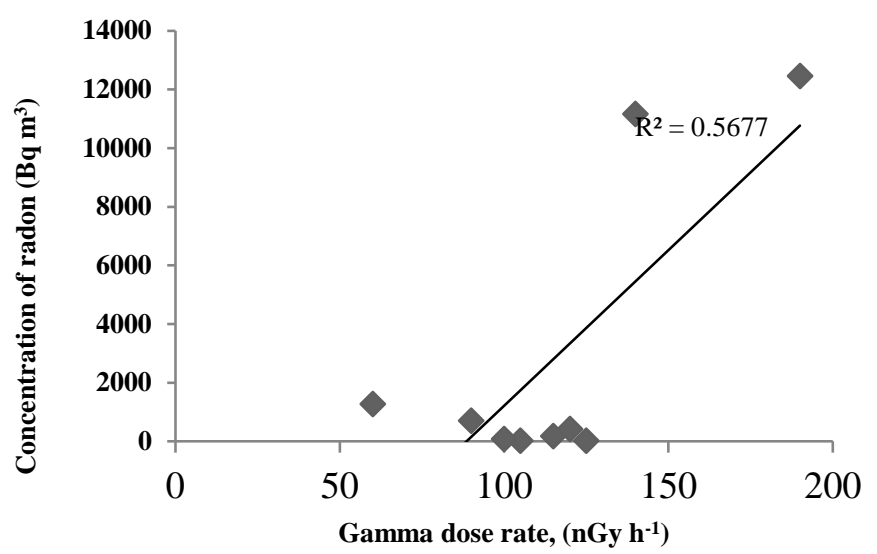

Fig 7. The relationship between the radon concentration and the gamma dose rate.

\section{CONCLUSION}

The vertical distribution of ${ }^{222} \mathrm{Rn}$ concentrations in soil gas was investigated for various soil types. The overall highest mean activity concentrations of ${ }^{222} \mathrm{Rn}$ was found at $40 \mathrm{~cm}$ depth with value of $4291 \pm 464 \mathrm{~Bq} \mathrm{~m}^{3}$. The overall lowest mean activity concentrations of ${ }^{222} \mathrm{Rn}$ was found at depth of $20 \mathrm{~cm}$ with value of $180 \pm 77 \mathrm{~Bq} \mathrm{~m}^{3}$. Most of the soil types recorded the highest activity concentration of ${ }^{222} \mathrm{Rn}$ at vertical profile depth of $40 \mathrm{~cm}$. The mean activity concentrations of ${ }^{222} \mathrm{Rn}$ in the study area was found to be $3166 \pm 246 \mathrm{~Bq} \mathrm{~m}^{-3}$, which was in good agreement with other researchers (Ali et al., 2010; Ali et al., 2011; Singh et al., 2010; King and Minissale, 1994; Bajwa et al., 2010; Abumurad and Al-Tamimi, 2005; Yasuoka et al., 2010; Sharman, 1993; Duggal et al., 2014). The relationship between radon concentration in soil gas and the measured gamma dose rate was determined, which revealed that there was a relationship.

\section{ACKNOWLEDGEMENT}

The authors would like to thank the Research Management Center (RMC), Universiti Teknologi Malaysia (UTM) for providing the support and funding under UTM Research university Grant; Q.J130000.2546.19H71.

\section{REFERENCES}

Abumurad, K., Al-Tamimi, M. (2005). Natural radioactivity due to radon in Soum region, Jordan. Radiation Measurements, 39: 77-80.

Ali K., Abdul, R. H., Ahmed R. S (2011) Measurement of radon concentration in soil gas using RAD7 in the Environs of Al-Najaf Al-Ashraf City-Iraq. Advances in Applied Science Research, 2011, 2 (5):273-278.

Ali, N., Khan, E., Akhter, P., Khan, F., Waheed, A. (2010). Estimation of mean annual effective dose through radon concentration in the water and indoor air of Islamabad and Murree. Radiation Protection Dosimetry, 141: 183191.

Audeem, W. F., Brian, K., Hajek, Joyce, E. M. (1993). OHIO State University, What Are the Sources of Ionizing Radiation? RER-22.

Bajwa, B. S., Singh, H., Sonikawade, R. G. (2010). Environmental radioactivity: A case study in HHP granitic region of Tusham ring complex Haryana, India. EGU General Assembly Conference Abstracts, p1888.

Department of Agriculture Peninsular Malaysia. (1973). Map of Soil Types in Peninsular Malaysia L-40A series 1st Edition. Kuala Lumpur, Malaysia.

Department of Statistics Malaysia. (2015). Basic Population Characteristics by Administrative District.

Duggal, V., Rani, A., Mehra, R. (2014). Measurement of soil-gas radon in some areas of northern Rajasthan, India. Journal of Earth System Science, 123: 1241-1247.

Durridge Company Inc. Products Soil Gas Probes. (2015). (n.d.). Retrieved from https://durridge.com/products/soil-gas-probes/ July 27.

Etiope, G., Martinelli, G. (2002). Migration of carrier and trace gases in the geosphere: An overview. Physics of the Earth and Planetary Interiors. 129 (3-4), 185-204.

King, C.-Y., Minissale, A. (1994). Seasonal variability of soil-gas radon concentration in central California. Radiation Measurements, 23: 683-692.

Nazaroff, W. William, Anthony, V. N. (1988). Radon and its Decay ProductsIn Indoor Air. John Willy \& Sons, chap. I, page 7.

Saffuwan, M. J., Zaidi, E., Mohd, N. D. (2012). A study of natural background radiation and $\mathrm{pH}$ level distribution of Malaysian soil species along Batu Pahat and Kluang, Johor. Nuclear Science, Technology \& Engineering Conference (Nustec), 23 May, Kuala Lumpur.

Saleh, M. A., Ramli, A. T., Alajeramie, Y., Suhairul, H., Aliyu, A. S., Basri, N. A. (2013). Terrestrial gamma radiation and its statistical relation with geological formation in the Mersing District, Johor, Malaysia. Radiation Protection Dosimetry, 156: 1-7.

Sharman, G. (1993). Relative abundance of radon-222 and radon-220 in soil gas in Northamptonshire and a preliminary assessment of indoor radon risk potential. Environmental Geochemistry and Health, 15: 2-3:187.

Sharma, N. Sharma R., Virk H. S. (2011). Environmental radioactivity: A case study of Punjab, India. Advanced in Applied Science Research, 2(3): 186190.

Singh, J., Singh, H., Singh, S., Bajwa, B. 2010. Measurement of soil gas radon and its correlation with indoor radon around some areas of Upper Siwaliks, India. Journal of Radiological Protection, 30: 63-71.

Yasuoka, Y., Sorimachi, A., Ishikawa, T., Hosoda, M., Tokonami, S., Fukuhori, N., Janik, M. 2010. Separately measuring radon and thoron concentrations exhaled from soil using alphaguard and liquid scintillation counter methods. Radiation Protection Dosimetry, 141(4):412-415. 